\title{
De SEMELHANÇA A SEMELHANÇA
}

\section{Georges Didi-Huberman}

* (BLANCHOT, Maurice. "Roman et poésie", Journal des débats, 7-8 de julho de 1941: 3. Citado por BIDENT, Christophe. Maurice Blanchot, partenaire invisible. Essai biographique. Seyssel: Champ Vallon, 1998: 147.)
* (BLANCHOT, Maurice. "La solitude essentielle" (1953). L'espace littéraire. Paris: Gallimard, 1998:31.)
A semelhança interminável (vasta como a noite)

A semelhança reunida, reconhecida, recluída, a semelhança evidente por si mesma nunca é senão uma salvação de aparência. A semelhança aquieta, ela nos afasta do hic. Mas, quando surge a semelhança - ou seja, quando ela aparece por aparição, por inevidência, por inquietude, por abertura e por estranhamento: quando, por exemplo, "a noite revela-se feita de órgãos e preenchida de uma espera física” -, ${ }^{*}$ ela não revela nada menos, seja por equívoco ou por desvio, que uma "verdade" fundamental impossível de ser dita de outra maneira. Maurice Blanchot, é o mínimo que se pode dizer, não trabalhava para salvar as aparências. E no entanto, durante muito tempo, e desde muito cedo, ele procurou na imagem e na semelhança uma condição essencial para a experiência que era a sua, como escritor e como leitor, a experiência da literatura.

Os livros de Blanchot ditos de crítica literária trazem sempre, em suas margens - entradas ou saídas -, alguma poderosa invocação às imagens e às semelhanças: $O$ Espaço Literário abre-se com um texto de 1953, "A solidão essencial”, que se desenvolve até fazer da imagem, isoladora e fascinante, o lugar e a questão próprios engajados no ato de escrever:

Escrever é entrar na afirmação da solidão em que o fascínio ameaça [...], é dispor a linguagem sob o fascínio e, por meio dela, permanecer em contato com o meio absoluto, ali onde a coisa se torna novamente imagem [...], a abertura opaca e vazia sobre o que é quando não há mais mundo, quando ainda não há mundo, [solidão essencial em que] a dissimulação aparece.*

Seria, portanto, imagem a habitante deste "meio absoluto" dado em abertura e como abertura ao "espaço literário"? Blanchot termina justamente seu texto com um ponto de interrogação e uma longa nota de rodapé na qual se questiona ainda a possibilidade de uma literatura entendida como "linguagem imaginária":

Será que a própria linguagem não se torna inteiramente, na literatura, imagem, não uma linguagem que conteria imagens ou que colocaria a realidade em figuras, mas que seria sua própria imagem, imagem de linguagem - e não uma linguagem figurada -, ou ainda 
linguagem imaginária, linguagem que ninguém fala, ou seja, que se fala a partir de sua própria ausência, assim como a imagem aparece sobre a ausência da coisa?*

Hipótese doravante suspensa a uma questão formulada - "o que é a imagem?" - em seguida, logo, remetida à outra extremidade da obra - "As duas versões do imaginário" - como sua improvável e impossível conclusão.* Em 1959, O livro por vir abria-se novamente com um texto intitulado "O encontro do imaginário", passível de ser lido como um prolongamento explícito da questão colocada alguns anos antes.* Em 1969, A conversa infinita reserva um de seus textos mais antigos - intitulado "Vasto como a noite" - à questão da imagem.* Em 1971, A Amizade abre-se ainda com um texto dedicado ao "Nascimento da arte" segundo Georges Bataille.*

Os textos de Blanchot sobre a imagem formam bem mais do que um simples parergon de seus textos sobre a literatura. É surpreendente, sem dúvida, que um desenvolvimento sobre a literatura tão rico em anáforas - quando "A solidão essencial" começa a repetir a expressão "Escrever é..." - pareça de repente distanciar-se de seu objeto específico e bifurcar da escrita à fascinação, do texto à semelhança ou da palavra à imagem. Como, além disso, a "neutralização do autor", reivindicada por Blanchot, autorizaria o antropomorfismo inerente às imagens? ${ }^{1}$ Ela o autoriza, no entanto, a ponto, mesmo, de exigi-lo vitalmente. Com a condição, é claro, de dar novamente sentido à imagem, esta "palavra culpada", como diz Blanchot invocando o "culpado" paradigmático de toda paixão pela imagem, Charles Baudelaire.* Com a condição, também, de renunciar às sempiternas casuísticas do paragone entre a palavra e a imagem: "Por que a coisa estaria separada entre a coisa que se vê e a coisa que se diz (se escreve)?* Afirmar que "a noite revela-se feita de órgãos”, por exemplo, não seria levar muito longe o jogo antropomórfico das semelhanças viscerais? Mas não seria também oferecer

\footnotetext{
${ }^{1}$ Surpresas expressas por Christophe Bident em Maurice Blanchot, partenaire invisible. Essai biographique. op. cit.: 309-311 e 328-333. Sobre as relações do imaginário com a literatura em Blanchot, cf. especialmente COLLIN, F. Maurice Blanchot et la question de l'écriture. Paris: Gallimard, 1971: 160-189 "'À quelles conditions la littérature est-elle possible?" - "L'Imaginaire"). SCHULTE NORDHOLT, A.-L. Maurice Blanchot. L'Écriture comme expérience du dehors. Génève: Droz, 1995: 193-225 ("L'Écriture, expérience de l'imaginaire"). ANTONIOLI, M. L'Écriture de Maurice Blanchot. Fiction et théorie. Paris: Kimé, 1999: 70-94 ("L'étrangeté littéraire" - Imaginaire et mimésis").
}

* (lbidem:31-32 (nota))

* (BLANCHOT, Maurice. "Les deux versions de l'imaginaire" (1951). L'espace littéraire. op. cit.: 341-355.)

*(BLANCHOT, Maurice. “La rencontre de l'imaginaire" (1954). Le Livre à venir. Paris: Gallimard, 1971: 9-19.)

* (BLANCHOT, Maurice. "Vaste comme la nuit" (1959). L'Entretien infini. Paris: Gallimard, 1969: 465477.)

* (BLANCHOT, Maurice. "Naissance de l'art" (1955). L'Amitié. Paris: Gallimard, 1971: 9-20.)

* (BLANCHOT, Maurice. "Vaste comme la nuit". L'Entretien infini. op. cit.: 471.)

* (BLANCHOT, Maurice. "Parler, ce n'est pas voir" (1960). L'Entretien infini. op. cit.: 40.) 
(BLANCHOT, Maurice "Vaste comme la nuit". L'Entretien infini. op. cit.: 467.)

* (Ibidem: 471 e 476-477.)

* (Ibidem: 470-472.)

(Ibidem: 474.)

* (Cf. DIDI-HUBERMAN, G. "L'image-matrice. Histoire de l'art et généalogie de la ressemblance" (1995). Devant Le temps. Histoire de l'art et anachronisme des images Paris: Minuit, 2000: 50-83. DIDI-HUBERMAN, G. L'Empreinte. Paris: Éditions du Centre Georges Pompidou, 1997: 38-84.)

* (BLANCHOT, Maurice. "Vaste comme la nuit". L'Entretien infini. op. cit.: 475 .) a imagem do homem a um espaço impessoal - vísceras não fazem uma pessoa - que se torna então "meio absoluto", "abertura opaca", neutralidade "vasta como a noite", ainda que orgânica? A imagem não é, portanto, o outro do neutro. Antes seu antro, no entre da coisa e do nada. Blanchot, que tinha podido encontrar em Sartre ou em Bachelard os elementos de uma reavaliação fenomenológica do imaginário, podia ler em Rilke ou em Kafka a colocação em prática - a colocação em texto - desta "abertura opaca" que caracteriza, segundo ele, uma imagem no sentido forte.

Não basta dizer - com Bachelard - que a imagem dá “a expressão original do poeta".* Implicar a noção de imagem na direção daquela de "abertura opaca" supõe refletir mais profundamente sobre o tempo de sua aparição. A imagem é "a forma do que aparece", escreve Blanchot. Ao mesmo tempo "abertura da irrealidade" e "torrente do exterior":* isto é, no ponto de contato entre os possíveis do imaginário e o impossível do real. $\mathrm{O}$ que isso implica para a linguagem e o pensamento? Que a aparição, via imagem, coloca a palavra "em estado de elevação": como se a escrita poética devesse sua própria intensidade à repercussão - primeiro tempo da imagem - de um ressoo:

[A imagem] é origem de linguagem e não seu abismo, ela é começo falante, mais do que o fim no êxtase, não elevando o que fala na direção do indizível, mas colocando a palavra em estado de elevação. [...] Só o que nos põe ao nível do poder poético é o ressoo, apelo da imagem ao que há de inicial nela, apelo que nos insta a sairmos de nós e a nos movermos no abalo de sua imobilidade. $\mathrm{O}$ "ressoo" não é, portanto, a imagem que ressoa (em mim, leitor, a partir de mim), ele é o próprio espaço da imagem, a animação que lhe é própria, o ponto de jorro no qual, falando dentro, ela já fala inteiramente fora.*

Nesse sentido, a imagem dará ao poema "seu segredo e sua profunda, sua infinita reserva".* Por exemplo, a palavra "vasto", em Baudelaire, parece a cada vez surgir de um "contra-mundo" - de uma reserva, de uma matriz ou de um negativo, como se diz para as moldagens, estes protótipos técnicos e antropológicos da noção ocidental de imago -* modo, segundo Blanchot, de "carregar toda a potência da palavra" na medida em que ela faz ressoar a aparição da noite na escrita. ${ }^{*}$ Apreendida segundo este tempo do ressoo, a imagem se desdobrará por meio de ondas ou de contatos sucessivos: "vasta como a noite" ou como o oceano. Evidência tanto quanto enigma: "A imagem é um enigma, assim que [...] fa fazemos surgir 
para colocá-la em evidência”.* Entre os dois - como na incerteza do momento em que o positivo de uma moldagem dissocia-se penosamente de sua matriz negativa, sob o risco de tudo destruir -, a imagem hesita, não sabe onde está, treme, se desmancha. Entre os dois - como no nem...nem do ne-uter -, aponta o neutro:

A imagem treme, ela é o tremor da imagem, o calafrio do que oscila e vacila: ela sai constantemente de si mesma, é que não há nada onde ela seja ela mesma, sempre já fora de si e sempre o dentro desse fora. [...] [Tal é] a imagem, para onde aponta o neutro". ${ }^{2 *}$

Assim desdobra-se a outra face, o outro tempo da imagem. $\mathrm{O}$ que era acontecimento tornar-se-á memória. O que era mônada tornar-se-á montagem. A aparição fez, no tempo de um relâmpago, sua marca: ela vai então durar de algum modo. Não como aparição, certamente (nada desaparece mais rapidamente do que uma aparição). Mas como fascínio, esta maneira que tem a imagem de manter-nos durante muito tempo, e mesmo indefinidamente, sob seu poder de assombração. Se escrever é estar só, estar só será estar diante da imagem, sob seu domínio, sua marca, sua potência: "Ali onde estou só [...] reina o fascínio" ** Ora, estar fascinado não é estar enganado: não é submeter-se à aparência enganadora das coisas, mas sofrer verdadeiramente sua aparição que retorna. É olhar "a impossibilidade que se faz ver".*

Mas ver o quê? O que se vê no fascínio? Blanchot responde: não a coisa, mas sua distância. E nossa própria solidão que daí resulta. É uma distância paradoxal, uma dupla distância - Benjamin a chamava de aura - de onde a imagem retira sua própria potência:

Ver supõe a distância, a decisão separadora, o poder de não estar em contato e de evitar no contato a confusão. Ver significa que essa separação tornou-se, porém, encontro. Mas o que acontece quando o que se vê, ainda que à distância, parece tocar-nos por um contato comovente, quando a maneira de ver é uma espécie de toque, quando ver é um contato à distância? [...] [Então] o olhar é arrastado, absorvido num movimento imóvel e para um fundo sem profundidade. O que nos é dado por um contato à distância é a imagem, e o fascínio é a paixão da imagem. ${ }^{3 *}$

${ }^{2}$ Cf. Maurice Blanchot. "Parler, ce n'est pas voir" (1960). L'Entretien infini. op. cit.: 42: "Da imagem também é difícil falar rigorosamente. A imagem é a duplicidade da revelação. $\mathrm{O}$ que vela ao revelar, o véu que revela ao re-velar na indecisão ambígua da palavra revelar, é a imagem. A imagem é imagem nessa duplicidade, não o duplo do objeto, mas o desdobramento inicial que permite em seguida que a coisa seja figurada".

${ }^{3}$ Cf. Maurice Blanchot. "Parler, ce n'est pas voir" (1960). L'Entretien infini. op.
* (BLANCHOT, Maurice. "La solitude essentielle" (1953). L'espace littéraire. op.cit.: 28.)

* (Ibidem: 23.)

* (Ibidem: 22-23.) 
*(BLANCHOT, Maurice. “La solitude essentielle" (1953). L'espace littéraire. op.cit.: 29-30.)

* (BLANCHOT, Maurice. Le Ressassement éternel. Paris: Minuit, 1951 (reedição in Après Coup. Paris: Minuit, 1983: 8-81). Maurice Blanchot. "Le musée, I'art et le temps" (1950-1951). L'Amitié. op. cit.: 46-49.)

* (BLANCHOT, Maurice. "Le musée, l'art et le temps" (1950-1951). L'Amitié. op. cit.: 44.$)$

* (Ibidem: 44 e 51.)
É preciso então compreender a imagem - com as semelhanças que ela faz constantemente elevar, proliferar, trabalhar em sicomo uma modificação fundamental da temporalidade. A imagem transforma o ressoo da aparição em reminação do fascínio: "Assim, o olhar encontra naquilo que o torna possível a potência que o neutraliza, que não o suspende nem o detém, mas, ao contrário, o impede de um dia terminar, que o corta de todo o começo, faz dele [...] o olhar do incessante e do interminável". Nesse momento, a semelhança "apreende a vista e torna-a interminável".*

A estética clássica teria tentado salvar as aparências: é por isso que ela "idealiza o instante", ou quer colocar as imagens da arte "ao abrigo das coisas perecíveis". Mas as imagens têm um inelutável devir que as faz e desfaz interminavelmente, para fazer de sua própria desaparição - ou de sua perda de vista temporal - o objeto de uma memória, de uma sobrevivência, de uma "ruminação eterna" como se expressa Blanchot, em 1951, na dupla frente da ficção e da reflexão estética.* Para além de Malraux - que no entanto ele comenta -, o autor de L'Arrêt de Mort terá imediatamente compreendido a imagem na escansão de uma temporalidade que não é nem o "intemporal", nem o "absoluto", nem o "eterno", mas a experiência impura da ruminação: um (kierkegaardiano) "tremor" do tempo duplicado de uma (nietzschiana) "eterna repetição".*

A partir daí vão se separar aparências e semelhanças, apaziguamentos e ameaças, belezas simples e belezas complicadas de perigos. A partir daí deve-se compreender - no próprio percurso que nos propõem os museus, ou a despeito de suas cronologias - que "a arte é ligada a tudo que coloca o homem em perigo [...]. Daí que o sangue, a angústia, a morte sejam em Goya o trabalho da arte". Quase acreditaríamos estar lendo Georges Bataille. Em todo caso, a imagem segundo Blanchot não é mais apenas - como em Sartre - um ato "capaz de negar o nada": ela é também "o olhar do nada sobre nós”.*Toda a dialética das "duas versōes do imaginário" já se diz nessas poucas palavras. Ela será posta à prova - e não por aca-

cit.: 39-41: “- Ver é, pois, apreender imediatamente à distância. - ... imediatamente à distância e pela distância. Ver é servir-se da separação, não como mediadora, mas como meio de imediação, como i-mediadora. [...] O fascínio se produz quando, longe de apreender à distância, somos apreendidos pela distância, investidos por ela...” É o que Foucault chamava a atração: "A atração é para Blanchot o que é, sem dúvida, para Sade o desejo, para Nietzsche a força, para Artaud a materialidade do pensamento, para Bataille a transgressão: a experiência pura do fora e a mais desnudada." FOUCAULT, Michel. "La pensée du dehors". Critique, XXII, 1966: 530. 
so - no exemplo batailliano de Lascaux: no qual, "com a figuração do homem [...], o homem pela primeira vez nasce de sua obra, mas [...] sente-se, também, gravemente ameaçado por ela e talvez já atingido de morte"; no qual a origem da arte é "ela própria sempre relacionada à não origem"; no qual "a juventude do que sempre começa e só faz começar” na imagem pré-histórica consagra a própria morte como interminável "recomeço".*

Se o mundo das semelhanças pode ser dito "vasto como a noite", é antes porque nunca se consegue acabar com uma semelhança: ela envia sempre para uma outra, ao menos. Mas é também por um conjunto de razões mais antropológicas (que constituem sistema ou, melhor, "versões" de um mesmo fenômeno). De um lado, a semelhança interroga o vivente e sua genealogia, o desejo e sua força; nesse sentido, dirá Blanchot, a imagem "é uma felicidade" inesgotável. "Sim, a imagem é felicidade, - mas perto dela permanece o nada, em seu limite ele aparece, e toda a potência da imagem, tirada do abismo no qual ela se funda, só pode exprimir-se apelando para ele".* A semelhança questiona-nos, portanto, também desde a morte: a imago é sempre a imagem daquele ou daquela que não existe mais. Ora, a própria morte é inesgotável e interminável para os viventes.

Ninguém a experimenta melhor do que o sonhador, sem dúvida: seu ponto de vista é, teoricamente - o que quer dizer, aqui: impossivelmente -, o melhor posto para observar aquilo de que uma imagem, de que uma semelhança são capazes. O sonho não se tece inteiramente por um interminável responso de semelhanças em que imagens de desejo e imagens de morte, desejos da imagem e mortes da imagem participam da mesma enigmática coreografia?

O sonho é o despertar do interminável [...]. O sonho toca a região onde reina a pura semelhança. Tudo nele é semelhante, cada figura nele é uma outra, é semelhante a outra, e ainda a uma outra, e esta a uma outra. Procura-se o modelo original, quer-se ser remetido a um ponto de partida, a uma revelação inicial, mas nada disso existe: o sonho é o semelhante que remete eternamente ao semelhante.*

\section{A semelhança impessoal (a jovem e a morte)}

Se o reino da imagem pode ser dito "vasto como a noite", é, portanto, sobretudo em razão desta perpétua remissão - ruminante - de semelhança a semelhança. Traços remetem a outros traços e
* (Ibidem: 51. Maurice Blanchot. "Naissance de l'art" (1955). L'Amitié. Paris: Gallimard, 1971: 19-20.)

* (BLANCHOT, Maurice. "Le musée, l'art et le temps" (1950-1951). L'Amitié. op. cit.: 50-51.)

* (BLANCHOT, Maurice. "Le sommeil, la nuit" (1955). L'espace littéraire. op. cit.: 361-362.) 
* (BLANCHOT, Maurice. "La solitude essentielle" (1953). L'espace littéraire. op.cit.: 30 .) criam, pouco a pouco, e depois por intervalos, uma superfície indefinidamente dobrada, desdobrada, redobrada. Nessa rede interminável, os aspectos passam ao pano de fundo das relações. Depois, as relações proliferam e passam ao pano de fundo de um efeito de meio, daquele "meio absoluto" invocado por Blanchot para descrever o tornar-se-imagem da linguagem na literatura. A semelhança é vasta como a noite, ou seja, como um meio impessoal, fluido mas opaco, espécie de intangível drapeado que envolveria todas as coisas e não teria mais fim.

Blanchot sabia bem, contudo, que se fala de semelhanças, na maioria das vezes, quando se fala de pessoas: assim fica-se admirado a cada nascimento que uma criança possa assemelhar-se à mãe. A semelhança parte frequentemente de um rosto, e não é fortuitamente que o próprio Blanchot tenha partido da figura materna para dar uma encarnação primeira do "encantamento" pela imagem:

Talvez a potência da figura materna tire o seu fulgor da própria potência da fascinação, e poder-se-ia dizer que, se a Mãe exerce essa atração fascinante, é porque, ao aparecer quando a criança vive inteiramente sob o olhar da fascinação, ela concentra em si todos os poderes de encantamento. É porque a criança está fascinada que a mãe é fascinante, e é também por isso que todas as impressões da primeira idade possuem algo de fixo que está ligado à fascinação.*

A semelhança parte de um rosto: dizer isso é dizer também que ela dele se separa, e mesmo dele se arranca. $\mathrm{O}$ rosto que nos apareceu e que ressoa em nós - rosto de uma pessoa amada, por exemplo - torna-se, na experiência da ruminação e da fascinação propriamente dita, o rosto de ninguém, um meio de semelhança sem ninguém a quem se assemelhar definitivamente. Então, escreve Blanchot nas mesmas linhas:

A fascinação está fundamentalmente vinculada à presença neutra, impessoal, ao Se $[\mathrm{On}]$ indeterminado, ao imenso Alguém sem rosto. Ela é a relação que o olhar mantém, relação ela própria neutra e impessoal, com a profundidade sem olhar e sem contorno, a ausência que se vê por ser ofuscante.*

A semelhança como tal não seria, portanto, nada mais do que seu próprio movimento, interminável, de semelhança a semelhança: do rosto aparecendo ao rosto retornando e deste ao fascinante "isto" sem rosto; da pessoa ao neutro; da forma isolável ao meio que tudo toma. Entre os dois estendem-se os múltiplos fios e as tramas de uma dramática da imagem cuja potência de paradoxo 
todos os exemplos escolhidos por Blanchot denotam muito bem: assim, quando ele escreve em 1951 que "os torsos realizam-se porque o tempo estilhaçou as cabeças"; ou que, simetricamente, "a face esmagada da Santa Élisabeth de Bamberg empresta a ela aquela semelhança noturna que ela manifestamente esperava”.*

"Os torsos realizam-se porque o tempo estilhaçou as cabeças". Apenas dirigindo um olhar para os célebres fragmentos da estatuária grega - frequentemente reproduzidos por Malraux* -, experimentamos rapidamente em que medida os torsos encontram-se, com efeito, intensificados por sua própria "ausência de pessoa”: eles tornam-se extraordinários meios onde se perder, verdadeiras "noites feitas de órgãos e preenchidas por uma espera física" solicitadas por sua potência corporal (os ombros, os seios, os ventres) tanto quanto têxtil (o drapeado, que corre como uma onda sobre tudo isso). No exemplo simétrico da Santa Élisabeth de Bamberg*, Blanchot é manifestamente arrebatado pela maneira como o artista e o tempo trabalharam em conjunto essa figura materna: era necessário emaciar o rosto para nele significar todas as suas "austeridades", toda a sua "temperança", sua "humildade" e sua "viuvez", conforme escrevia Voragine sobre a santa.* Era necessária uma boca na qual os lábios recuam para o interior. Era necessário tornar oco o olhar e esconder a cabeleira sob um véu que já se assemelha a um sudário. Era necessário "esmagar a face", como diz Blanchot, para que surgisse desde logo o "imenso Alguém sem rosto”. Era necessário, enfim, que um rosto de mãe pudesse rimar visualmente com uma máscara de morte. Mesmo "as cores se decompõem", observa Blanchot sobre esta estátua outrora policromática, "e esta dissolução é a recompensa da arte, assim reconciliada com a ausência”.*

Figura $1^{*}$

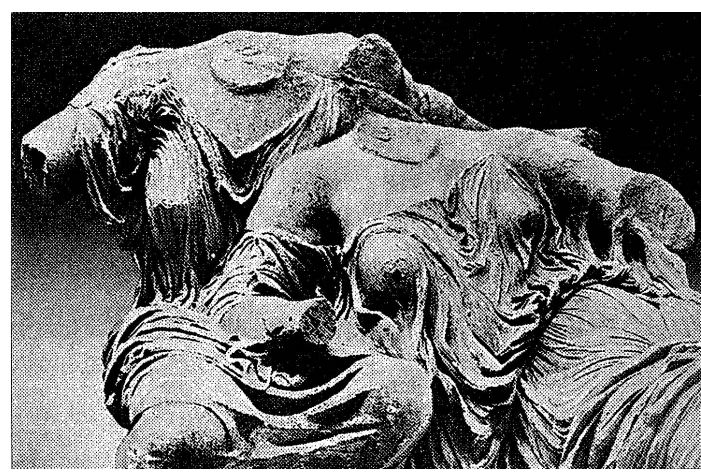

* (BLANCHOT, Maurice. "Le musée, l'art et le temps" (1950-1951). L'Amitié. op. cit.: 45.$)$

* (figura 1)

* (figura 2)

* (VORAGINE, Jacques de. La légende dorée (vers 1263). Trad. J.-B. Roze (1900). Paris: Garnier-Flammarion, 1967: II, 348-367.)

* (BLANCHOT, Maurice. "Le musée, l'art et le temps" (1950-1951). L'Amitié. op. cit.: 45.)

* Figura 1: Anônimo grego. Afrodite e Dione, aprox. 440-432 A.C. Mármore (proveniente do frontão do Parthenon). Londres, British Museum. Cf. André MaIraux. Le Musée imaginaire de la sculpture mondiale. Paris: Gallimard, 1952, I, fig. 142. 
* Figura 2: Anônimo alemão. Santa Élisabeth, metade do século XIII. Calcário. Bamberg, Catedral. Cf. André Malraux. Le Musée imaginaire de la sculpture mondiale. Paris: Gallimard, 1952, I, fig. 554.
Figura $2^{*}$

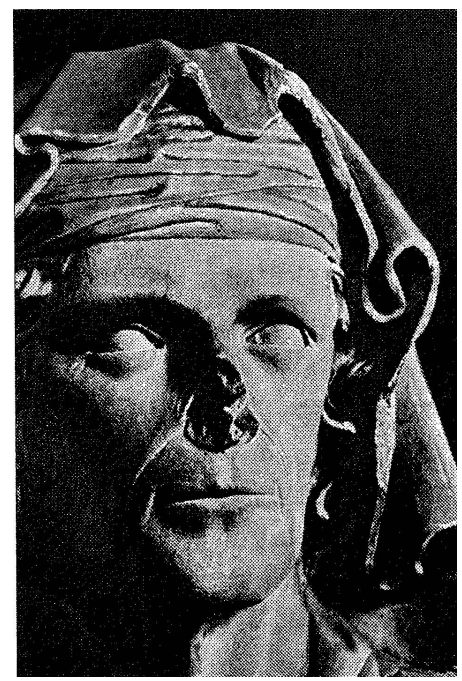

É exatamente esta a duplicidade da imagem, este "duplo sentido inicial que a potência do negativo traz consigo", e da qual o texto sobre "As duas versões do imaginário" dá uma formulação tão completa quanto concisa. A referência freudiana permitirá, entre outras coisas, ultrapassar as triviais oposiçôes entre o imaginário (como ficção) e o real (como verdade):

A psicanálise diz assim que a imagem, longe de nos deixar fora de causa e de nos fazer viver no modo da fantasia gratuita, parece entregar-nos profundamente a nós mesmos. Íntima é a imagem, porque ela faz de nossa intimidade uma potência exterior a que nos submetemos passivamente: fora de nós, no recuo do mundo que ela provoca, arrasta-se, desgarrada e brilhante, a profundidade de nossas paixōes. [...].

Viver um acontecimento em imagem não é ter desse evento uma imagem nem tampouco dar-lhe a gratuidade do imaginário. O acontecimento, nesse caso, tem lugar verdadeiramente e, no entanto, terá ele lugar "verdadeiramente"? O que acontece nos arrebata, como nos arrebataria a imagem, ou seja, nos despoja, de si e de nós, mantém-nos de fora, faz desse fora uma presença em que o "Eu" não "se" reconhece. [...] Essa duplicidade não é tal que se possa pacificá-la por meio de um ou isto ou aquilo, capaz de autorizar uma escolha e de apagar da escolha a ambiguidade que a torna possível. Essa duplicidade remete ela própria a um duplo sentido sempre mais inicial. [...] Aqui, o sentido não escapa para um outro sentido, mas para o outro de todo sentido e, por causa da ambiguidade, nada tem sentido, mas tudo parece ter infinitamente sentido: o sentido não é 
nada além de uma aparência, a aparência faz com que o sentido se torne infinitamente rico [...].*

Eis por que as semelhanças nos encantam de um lado e nos inquietam de outro. Uma imagem seria sempre algo como a jovem e a morte reunidas em uma única coisa fascinante.* Blanchot o exprime falando da "felicidade da imagem" - seu feminino poder de "apaziguar, de humanizar o informe nada que o resíduo ineliminável do ser impele em nossa direção" -, e depois de um encantamento que se transforma em "magia negra" e, enfim, de um mortal reencontro das formas "com o fundo, [...] com a materialidade elementar, a ausência ainda indeterminada de forma”. A imagem nos encanta por saber dar forma a todas as coisas, ela nos inquieta por saber logo enterrar-se a si própria, e a todas as coisas, "na prolixidade informe da indeterminação".* A interminável remissão de semelhança a semelhança produz a interminável escansão de uma beleza que nos forma e de uma dissolução que nos envia ao fundo.

Figura $3^{*}$

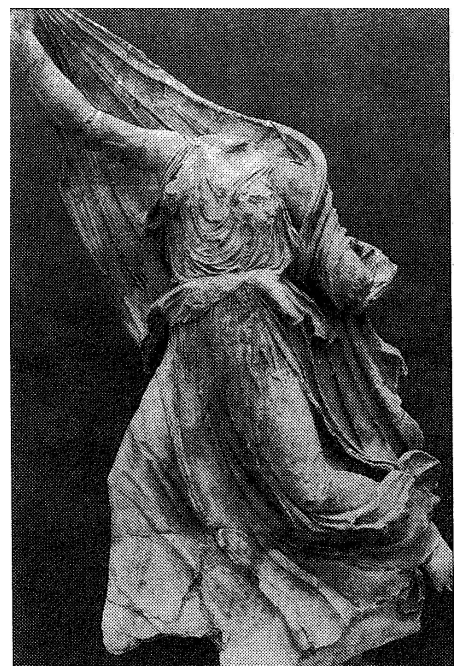

Esse modelo dialético da imagem atravessa todo o pensamento de Maurice Blanchot, mesmo quando ele se obstina a esclarecer o que escrever quer dizer. Assim começa, ou recomeça, O Livro por Vir: não procurando discriminar o olhar do canto e o da escrita, por exemplo, mas nomeando o "êxtase temporal" comum - termo proustiano - que os reúne na mesma experiência de "encontro do imaginário". Primeiras palavras, primeiras figuras do livro: "As
* (BLANCHOT, Maurice. "Les deux versions de l'imaginaire" (1951). op. cit.: 352-354.)

* (figura 3)

* (Ibidem:341-342 e 352353.)

* Figura 3: Anônimo grego da Ásia Menor (Xanthos). Túmulo das Nereidas (detalhe), final do século V-IV A.C. Mármore. Londres, British Museum. Foto feita por Georges Didi-Huberman. 
* (BLANCHOT, Maurice. "La rencontre de l'imaginaire" (1954). Le Livre à venir. op. cit.: 9.)

* (lbidem: 9-19.)

* (BLANCHOT, Maurice. “Le regard d'Orphée" (1953). L'espace littéraire. op.cit.: 225-226.)

* (BLANCHOT, Maurice. Au moment voulu. Paris: Gallimard, 1951: 7.)
Sereias".* Elas encarnam, é claro, o encantamento do canto. Mas tudo o que Blanchot diz delas nos faz também compreendê-las como as personificações do que, em Espaço Literário, ele chamava de imagem. É, portanto, uma única e mesma experiência aproximar-se do canto das Sereias e encontrar a imagem.

Então, o "defeito" faz-se "potência"; então, se impõe uma fascinação própria para suscitar "a abertura deste movimento infinito que é o próprio encontro, [...] seu recomeço eterno”; mas persiste uma vaga suspeita de logro, de magia negra; a distância far-se-á, contudo, revelação e "possibilidade de percorrer essa distância; então, o que revela será capaz de desaparecer por si mesmo no ato de revelar; então, estaremos sob o encantamento da imagem-Sereia. Ulisses tenta captar sua bela forma sem ser ele próprio captado por sua profundidade (fazendo-se atar ao mastro do navio, ele "mantém um limite e este intervalo entre o real e o imaginário que, precisamente, o canto das Sereias o convida a percorrer"). Achab, por sua vez, aceitará conhecer o fundo, ou seja, afogar-se nele.* Quanto a Orfeu, ele terá querido fazer de seu olhar em direção a Eurídice "a experiência desmedida da profundidade": pois Eurídice era para ele "a potência pela qual a noite se abre [...], o ponto profundamente obscuro para o qual parecem tender a arte, o desejo, a morte". ${ }^{4 *}$ Outra versão da "dupla versão": a Eurídice mortal (ou seja, pessoal e atingível) estaria para a Eurídice morta (ou seja, impessoal e infernal) como a imagem-forma está para a imagem-meio, ou como a semelhança-encanto está para a semelhança-dissolução.

Ora, é exatamente dessa maneira - dialética - que Blanchot constrói alguns de seus personagens literários (com o objetivo, é claro, de atingir a potência impessoal que, ao fim das contas, os tornará fascinantes). Desde a primeira linha de Au moment voulu, uma jovem mulher abre a porta: arrebatamento do encontro. "Minha surpresa foi extrema, inextricável, muito maior, certamente, que se eu a tivesse encontrado por acaso."* Esta jovem mulher fora conhecida outrora. Mas, ao reaparecer,

[...] ela era perfeitamente a mesma, não apenas fiel aos seus traços, à sua aparência, mas à sua idade: de uma juventude que a tornava estranhamente semelhante. Eu não parava de olhá-la, eu pensava: Eis, portanto, de onde vinha meu espanto. Seu rosto, ou antes, sua

\footnotetext{
${ }^{4}$ Sobre o tema de Orfeu em Blanchot, cf. especialmente C. Michel. Maurice Blanchot et le déplacement d'Orphée. Saint-Genouph: Nizet, 1997. P Fries. La Théorie fictive de Maurice Blanchot. Paris: L'Harmattan, 1999: 244-256 ("Orphée et Eurydice: le mythe central").
} 
expressão, que quase não variava, a meio caminho entre o sorriso mais alegre e a reserva mais fria, ressuscitava em mim uma lembrança terrivelmente longínqua, e era essa lembrança, profundamente enterrada, mais do que velha, que ela parecia copiar para aparentar tanta juventude.*

O tempo passou e, no entanto - mas seria preciso dizer: é por isso que -, a semelhança está aí, semelhança de uma mulher com a jovem que ela foi. As paixões agiram, e, no entanto - é por isso que -, o rosto dessa mulher apresenta hoje uma semelhança tão paradoxal quanto soberana, situada a meia distância entre o "sorriso mais alegre" e a "reserva mais fria". Ora, tudo isso surge de um só golpe, no tempo de uma porta que se abre: no instante de uma aparição que faz surgir, por semelhança interposta ou imposta, uma lembrança "mais do que velha", provavelmente "decomposta" como os pigmentos sobre a estátua de Bamberg. Se essa mulher que abre a porta é "estranhamente semelhante", é porque oferece ao olhar, entre pura juventude e trabalho do tempo, um rosto reminiscente, ou de retorno, do interminável.

Já L'Arrêt de Mort refreia esses paradoxos, como se a semelhança marcasse a cada vez uma parada na imagem, suspensa entre a jovem e a morte. Uma mulher "vivia de galanteria"? O narrador a "supõe morta".* Os amantes se aproximam? Uma "barreira" surge para separá-los, "a do pano morto sobre um corpo silencioso, daquelas roupas [...] impregnadas de insensibilidade, com suas pregas cadavéricas e suas inércias de metal" ou de pedra.*

Mas é, evidentemente, a morte de J. que, na narrativa de Blanchot, concentrará todo esse drama - temporal tanto quanto visual - da semelhança. Doente, já tomada no trabalho de sua agonia, a jovem começa a se assemelhar à sua própria adolescência: "O principal efeito da doença era o de lhe dar traços de uma adolescente."* Após a sua morte, ela reencontrará - num último anacronismo aquela beleza de ninfa que ela já havia, no entanto, deixado: "Após a morte, sabe-se que os seres belos voltam a ser, por um instante, jovens e belos."* Nesse intervalo, a semelhança de jovem, pura e fechada sobre si mesma, abre-se e desaba na semelhança, impura e escancarada, de uma "boca aberta sobre o ruído da agonia".* Georges Bataille não está muito longe, ${ }^{5}$ exceto pelo fato de que Blan-

\footnotetext{
${ }^{5}$ Sobre as relaçóes entre a agonia de J. e a de Laure, $c f$. Cristophe Bident. Maurice Blanchot, partenaire invisible. Essai biographique. op. cit.: 291. Sobre o motivo batailliano da abertura, $c f$. Georges Didi-Huberman. "L'immagine aperta". Tradução M. Galletti. J. Risset (org.). Georges Bataille: Il político e Il sacro. Na-
}

* (lbidem: 8-9.)

* (BLANCHOT, Maurice. L'Arrêt de mort. Paris: Gallimard, 1948: 9.)

* (lbidem: 113.)

*(Ibidem: 12.)

* (Ibidem: 28.)

* (Ibidem: 49.) 
* (Maurice Blanchot. L'Arrêt de Mort. op. cit.: 35,50 e 52.) chot tende a petrificar a crise, como se fosse necessário enrolar a escrita no processo - físico e psíquico - pelo qual o sobressalto de um sintoma trabalha em sua própria mineralização:

Ela estava um pouco mais deitada do que eu teria imaginado, com a cabeça repousando sobre uma almofadinha e tendo, por essa razão, a imobilidade de uma jacente e não de uma pessoa viva. $\mathrm{O}$ rosto era sério e até mesmo severo. Os lábios, comprimidos, faziam pensar na violência dos dentes que, cerrados no último segundo, mesmo agora não se descontraíam. As pálpebras também estavam curvadas. A pele, de uma brancura admirável pelo brilho negro dos cabelos, apertou-me o coração. Ela já não passava de uma estátua, ela absolutamente viva. [...] As idas e vindas ao quarto pareciam completamente alheias a esse corpo inconsciente, ele próprio alheio à sua própria agonia. [...], tornando-se esse corpo cadavérico. [...] Dois ou três minutos mais tarde, seu pulso desregulou-se, acusou um golpe violento, parou, depois recomeçou a bater fortemente para parar novamente, isso várias vezes, enfim tornou-se extremamente rápido e minúsculo, e "dispersou-se como areia”.

Não tenho meios para escrever mais sobre isso. Eu poderia acrescentar que, durante aqueles instantes, J. continuou a me olhar com o mesmo olhar afetuoso e aquiescente e que aquele olhar dura ainda, mas isso infelizmente não é certo.*

Toda a constituição da imagem, todo o seu poder e toda a sua incerteza aparecem nessas poucas linhas. Tempo da aparição e da ressonância: o corpo se petrifica como gesso, a vida se dispersa como areia, a imagem permanece entre esses dois estados contraditórios. Tempo da fascinação e da ruminação: "Esse olhar dura ainda, mas isso infelizmente não é certo.” O que é certo, contudo, é que a obsessão desse olhar - a soberania da imagem - não cessará, ainda que a semelhança interminável seja uma interminável falha, uma interminável lacuna, portanto uma interminável infelicidade: "Essa força demasiadamente grande, incapaz de ser arruinada por nada, nos condena talvez a uma infelicidade sem medida, mas, se assim for, tomo essa infelicidade para mim e regozijo-me com ela sem medida e, a ela, digo eternamente: 'Venha', e eternamente, ela está aí."**

\section{A semelhança dessemelhante (inacessível como a vida)}

O reino da imagem começa talvez quando uma jovem é morta. Seu olhar vai durar, "mas isso infelizmente não é certo" (e a 
imagem se atém justamente a esse equívoco). Sua semelhança vai se transmitir, "e eternamente, ela está aî" (o que quer dizer que ela não está aqui, e, portanto, que não é inteiramente dela a aparição que ruminaremos daqui por diante). Na medida mesmo em que é uma narrativa de sobrevivência, ${ }^{*}$ pode-se dizer que L'Arrêt de mort desenvolve a afinidade essencial da imagem com o tempo, com o "assustadoramente antigo"* de sua solicitação. Nada é mais antigo do que a morte, sabe-se, e assim se explica a antiguidade das imagos; mas Aby Warburg também mostrou, em sua arqueologia da ninfa, que nada era mais antigo do que a própria jovem.*

A imagem assemelha-se ao que a solicitou - o rosto de um morto ou de uma morta, por exemplo -, mas não se assemelha a ele. Ela o deixa em sua dispersão primeira, em seu equívoco fatal, em sua necessária inacessibilidade. Há assim, em L'Arrêt de mort, uma exata proporcionalidade entre a solidificação da imagem e a dissolução da vida. No médico, guardiāo das mortais prediçōes, o narrador vê "distintamente os traços de um rosto de mulher extremamente belo e até mesmo esplêndido" na trama de uma fotografia do Santo Sudário pregada na parede; além disso, trata-se de uma "belíssima moldagem das mãos de J.", com suas linhas "inteiramente singulares, entrecortadas, emaranhadas", reveladoras de uma "sorte trágica"; enfim, será evocado o desejo de "embalsamar" a jovem morta, "essas práticas [sendo] julgadas insalubres, para não dizer mais".*

O próprio Blanchot sugeriu que terminara em Èze L"Arrêt de mort sob o olhar de gesso, poder-se-ia dizer, de uma imagem de jovem morta célebre: “[...] havia (ela ainda está lá), pendurada na parede, a efígie daquela que foi chamada $A$ Desconhecida do Se$n a$, uma adolescente de olhos fechados, mas viva por meio de um sorriso tão solto, tão afortunado (velado, contudo), que se poderia crer que ela se afogara num momento de extrema felicidade".** Não sei se a efígie em questão era uma simples fotografia ou - mais verossimilmente - um molde em gesso tal como era fácil de obter, naqueles anos, da mesma forma que os bustos de Beethoven ou de Napoleão. De toda maneira, A Desconhecida do Sena, heroína impessoal por excelência, já havia inspirado alguns escritores tais como Aragon, Supervielle, Ödon von Horvath e, sobretudo (aos olhos de Blanchot), Rainer Maria Rilke, que a evoca nos seus Cahiers de Malte Laurids Brigge: "O moldador diante de cuja loja passo todos os dias pendurou duas máscaras na sua porta. O rosto
* (Cf. DERRIDA, Jacques. "Survivre". Parages. Paris: Galilée, 1986: 117-218.)

* (Cf. LAPORTE, Roger. Maurice Blanchot. L'ancien l'effroyablement ancient. Montpellier: Fata Morgana, 1987.)

* (Cf. DIDI-HUBERMAN, Georges. L'Image survivante. Histoire de l'art e temps des fantômes selon Aby Warburg. Paris: Minuit, 2002: 335-362.)

* (BLANCHOT, Maurice. L'Arrêt de mort. op. cit.: 19, 21-22 e 38 (a eficácia da "máscara" na narrativa fo analisada por P. Madaule. "L'événement du récit". Revue des sciences humaines, número 253, 1999: 85-86.

* (figura 4)

* (BLANCHOT, Maurice. Une voix venue d'ailleurs. Sur les poèmes de LouisRené des Forêts. Plombières-lès-Dijon: Ulysse Fin de Siècle, 1992: 13. Cf. BIDENT, Christophe. Maurice Blanchot, partenaire invisible. Essai biographique. op. cit.: 280-281.) 
* (RILKE, Rainer Maria. Les Cahiers de Malte Laurids Brigge (1904-1910). Tradução de M. Betz. CEuvres, I, Proses. Edição P. de Man. Paris: Le Seuil, 1966: 597. Sobre a fortuna crítica da Desconhecida do Sena, cf., PINET, H. "L'eau, la femme, la mort. Le mythe de L'Inconnue de la Seine". Le Dernier Portrait. HÉRAN, E. (org.). Paris: Musée d'Orsay-RMN, 2002 : 175-190.)

* Figura 4: Anônimo francês. A Desconhecida do Sena, aprox. 1898-1900. Gesso. Saint-Denis, Atelier des moulages de la Réunion des Musées Nationaux. Foto de D. R.

* (BLANCHOT, Maurice. "La solitude essentielle" (1953). L'espace littéraire. op.cit.: 24.)

* (BLANCHOT, Maurice. "L'œuvre et l'espace de la mort". L'espace littéraire. op.cit.: 103-209.) da jovem afogada que havia sido moldado no necrotério, porque era belo, porque sorria, porque sorria de maneira tão dissimulada, como se soubesse.”*

Figura $4^{*}$

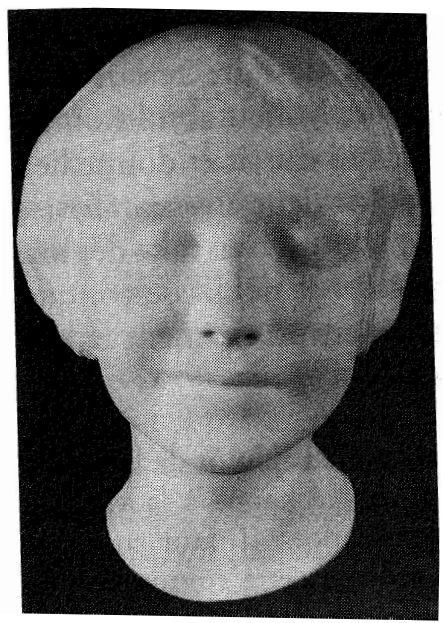

O paradoxo dessa efígie relaciona-se talvez ao fato de ela ter sido totalmente reproduzida apenas ao final, seus traços estavam quase se apagando, a começar pelos cílios, as pálpebras, os cabelos - num curioso efeito de velamento leitoso. A Desconhecida do Sena é considerada como tendo sido um pobre cadáver de jovem afogada tornada molde e capaz, desde então, de retornar a este "meio absoluto, onde a coisa volta a ser imagem".* Meio absoluto no qual os rostos se afogam nesta espécie de leite calcário que enrijece e dá lugar a imagens. No qual desaparecer (dispersar-se como vida) equivale a assemelhar-se (solidificar-se como imagem). Quando afirma que a obra se desdobra fundamentalmente no "espaço da morte",* Blanchot não deixa entender que esse espaço, "vasto como a noite", é precisamente habitado por uma semelhança que se desconjuntou da vida?

A semelhança não é um meio de imitar a vida, mas antes de torná-la inacessível, de estabelecê-la num duplo fixo imóvel que, ele, escapa à vida. As figuras vivas, os homens, são sem semelhanças. É preciso esperar a aparência cadavérica, essa idealização pela morte e essa eternização do fim, para que um ser tome essa beleza maior que é sua própria semelhança, essa verdade dele próprio num reflexo. Um retrato, isso foi percebido pouco a pouco, não é semelhante porque se faria similar ao rosto, mas a semelhança só começa e só existe com o retrato e apenas nele, ela é sua obra, sua glória ou sua desgraça, ela 
está ligada à condição de obra, exprimindo este fato de que o rosto não está aí, ele está ausente, ele só aparece a partir da ausência que é precisamente a semelhança, e essa ausência é também a forma como o tempo se apreende, quando se distancia o mundo, e, dele, nada mais resta a não ser esse desvio e esse distanciamento.*

A semelhança desconjunta: ela cria a relação, mas não a unidade. Ela cria a relação para melhor escavá-la. Ela divide o ser. Ela impóe o desvio no momento mesmo em que propóe o contato. "Tornada imagem, instantaneamente, ei-la [a coisa] tornada a inapreensível, a inatual, a impassível, não a mesma coisa distanciada, mas essa coisa como distanciamento."* É preciso então compreender a semelhança como o que desconjunta o rosto de sua vida. Colocação à distância - à estranheza - que constitui para acabar, aos olhos de Blanchot, a própria caracterização da imagem: "Talvez a estranheza cadavérica fosse também a da imagem."**

Esse desvio forma, precisamente, o neutro (ne... uter): "Algo está aí, diante de nós, que não é nem o ser vivo em pessoa, nem uma realidade qualquer, nem o mesmo que aquele que vivia, nem um outro, nem outra coisa. [...] A presença cadavérica estabelece uma relação entre aqui e parte alguma [...], imagem insustentável e figura do único tornando-se não importa o quê".* A imagem retira, portanto, sua necessidade justamente dessa "neutralidade": nem o único (a unidade ontológica do ser reunido em si mesmo) nem o não importa o quê (a vaidade das aparências em que o ser se dispersa inteiramente).

Mas como pensar isso com noções? O que Blanchot exige não ultrapassa os limites habituais de uma filosofia escolar? O que ele faz senão contornar as vias da filosofia profissional e praticar - como seu amigo Bataille - uma maneira de heterologia? Michel Foucault, falando em Blanchot de um "pensamento do fora”, não visava justamente essa dialética heterodoxa, esse pensamento em batimento de asas - "nem um nem outro" - de onde a imagem retira sua própria necessidade?* Emmanuel Lévinas - outro amigo, outro leitor de Blanchot - disse-o de uma maneira mais diretamente polêmica: o que está em jogo em todos os paradoxos desse pensamento - em particular na ideia de uma semelhança desconjunta$\mathrm{da}$ - não seria outra coisa que não um desenraizamento da ontologia heideggeriana, nada menos:

Já para Heidegger a arte, além de toda significação estética, fazia luzir a "verdade do ser", mas ela tinha isso em comum com outras
* (BLANCHOT, Maurice. "Le musée, l'art et le temps" (1950-1951). L'Amitié. op. cit.: 42-43.)

* (BLANCHOT, Maurice. "Les deux versions de l'imaginaire" (1951). L'espace littéraire. op. cit.: 344.)

* (Ibidem: 344.)

* (Ibidem: 344-346. Grifo do autor.)

* (FOUCAULT, Michel. "La pensée du dehors". op. cit.: 543-546.) 
*(LÉVINAS, Emmanuel. “Le regard du poète" (1956). Sur Maurice Blanchot. Montpellier: Fata Morgana, 1975: 19-25.)

* (BLANCHOT, Maurice. "Les deux versions de l'imaginaire" (1951). L'espace littéraire. op. cit.: 346-347.) formas de existência. Para Blanchot, a vocação da arte é sem par. Mas, acima de tudo, escrever não conduz à verdade do ser. Poder-se-ia dizer que ela leva ao erro do ser - ao ser como lugar de errância, ao inabitável. [...] Para Heidegger, a verdade - um desvelamento primordial - condiciona toda errância e é por isso que todo o humano pode se dizer no final das contas em termos de verdade, descrever-se como "desvelamento do ser". Em Blanchot, a obra descobre, uma descoberta que não é verdade, uma obscuridade [...] absolutamente exterior sobre a qual apreensão alguma é possível. Como num deserto, não se pode nela encontrar domićlio. Do fundo da existência sedentária ergue-se uma lembrança de nômade. O nomadismo não é uma aproximação do estado sedentário. É uma relação irredutível com a terra: uma estadia sem lugar. [...] O espaço literário ao qual nos conduz Blanchot [...] não tem nada em comum com o mundo heideggeriano que a arte torna habitável. [...] Blanchot não empresta à arte a função de desenraizar o universo heideggeriano?*

A imagem corresponde exatamente a essa exigência, caso se aceite pensar que ela cobre com um véu que não é mentira, e que ela descobre com um descobrir que não é verdade. Ela é tanto ontologicamente necessária quanto é instável e ontologicamente dissociada. Assim, ao fazer dos "despojos" o próprio paradigma da imagem, não estaria Blanchot pretendendo fazer justiça a todos esses paradoxos? O que são, aliás, despojos? É, primeiramente, algo que toma, que se concretiza ou se enrijece: é o momento no qual o cadáver torna-se essa espécie de efígie de si próprio, endurecida - mas tão frágil - como um monumento de cera ou de gesso:

[...] neste momento em que a presença cadavérica é diante de nós a do desconhecido, é então também então que o defunto pranteado começa a se assemelhar a si mesmo. [...] Si mesmo designa o ser impessoal, distanciado e inacessível, [...] imponente, já monumental e tão absolutamente si mesmo que é como que duplicado por si, unido à solene impessoalidade de si pela semelhança e pela imagem, [...] semelhante num grau absoluto, perturbador e maravilhoso. Mas a que se assemelha?*

Em seguida, os despojos são algo que se arranca de si próprio: estranho equívoco de uma palavra que significa o corpo "em pessoa”, mas também seu duplo impessoal, sua pobre pele animal que dele é arrancada para deixá-la de lado, até mesmo para expô-la na parede como um troféu de caça, como uma imagem. Estranho equívoco de uma palavra que fala do desnudamento - "despojar-se" até a abertura, e da abertura até a morte. Bataille, decididamente, nunca está muito longe. Enfim, os despojos são algo que se desloca 
interminavelmente, para além de toda fixidez intrínseca. Como os quadros que são transportados de galeria a galeria, como as imagens mentais que não cessam de se mover em nós, de passar por um caminho e repassar por um outro. É o essencial nomadismo da imagem. Eis por que Blanchot insiste nesse novo paradoxo da imagem-despojo, a saber, que ela é "fixa" (como uma efígie de gesso) e, no entanto, "sem repouso" (como uma obsessão impossível de ser contida). Dizer que a semelhança é interminável não é significar que ela é ao mesmo tempo "fixa e sem repouso", imobilizada como uma máscara funerária e movente como uma noite "plena de espera física?”

A semelhança cadavérica é uma obsessão, mas o fato de obcecar não é a visitação irreal do ideal: o que obceca é o inacessível de que não podemos nos desfazer, o que não encontramos e que, por isso, não se deixa evitar. O inapreensível é aquilo a que não se escapa. A imagem fixa não tem repouso, sobretudo no sentido de que não afirma nem estabelece nada. [...] Por mais que o cadáver esteja tranquilamente estendido em seu leito de velório, ele nem por isso deixa de estar em toda parte, no quarto, na casa.*

Ora, o despojo é também uma palavra técnica dos procedimentos de moldagem. É uma declividade que se manuseia em certas partes do modelo para facilitar sua saída, sua separação do molde. A “peça de despojo" é um segmento do molde que corresponde geralmente à impressão de uma saliência, e que se remove facilmente após a fundição da prova (ao contrário, a "peça de contra-despojo" corresponde às cavidades pouco acessíveis, cujo fundo é, por exemplo, maior do que a abertura). * Uma inquietante analogia já conjugava os temas do "contra-mundo" ou da "reserva" - invocados por Blanchot para qualificar a dimensão imaginária como tal - com o vocabulário da impressão, "matriz", "contramolde" ou "retração". Ela encontra no despojo sua última eficácia, e explica por que, nos textos de Blanchot, é, às vezes, difícil saber se a imagem do morto designa o próprio cadáver, seu molde funerário ou o registro - fotográfico, por exemplo - desta ou daquela.

Mas em que medida essa noção da imagem-despojo escaparia, para terminar, ao cânone filosófico? Em que medida, sobretudo, ela não teria "nada em comum com o mundo heideggeriano que a arte torna habitável”, segundo a expressão de Emmanuel Lévinas? Heidegger não pensou a imagem - como todo o resto - em relação estreita com a questão da morte? Além disso, ele não situou a máscara
* (Ibidem: 348.)

* (Cf. BAUDRY, M.-T. (org.). Principes d'analyse scientifique. La sculpture: méthode et vocabulaire. Paris: Imprimerie Nationale, 1990: 562-563.) 
*(HEIDEGGER, Martin. Kant et le problème de la métaphysique (1925-1928). Tradução de A. de Waelhens et W. Biemal. Paris: Gallimard, 1953 (ed. de 1998): 150-152.)

* (Cf. NANCY, Jean-Luc, "L'imagination masquée" (2002). Au fond des images. Paris: Galilée, 2003: 165166. Trata-se, de fato, de E. Benkard (Das ewige Antlitz. Eine Sammlung Von totenmasken. Berlim: Frankfurter Verlagsanstalt, 1926), e não de "Bankard", como escreve Nancy. Uma edição mais recente dessa coleção se deve a U. Ott e F. Pfäfflin (dir.). Archiv der Gesichter. Toten-und Lebendmasken aus dem Schiller-Nationalmusuem. Marbach am Neckar: Deutsche Schillergesellschaft, 1999.) mortuária no centro de sua definição da imagem? Recordemo-nos, com efeito, como Heidegger reconstruía a linha de continuidade clássica entre o modelo e sua imagem, ou seja, entre a imagem no sentido da "visão imediata" (unmittelbarer Anblick) de uma coisa e a imagem no sentido do "decalque" (Abbid) dessa coisa:

Normalmente, chama-se de "imagem" (Bild) a visão (Anblick) oferecida por um ente determinado na medida em que ele se manifesta como dado. Esse ente oferece uma visão [de si próprio]. De acordo com um sentido derivado, chamar-se-á de “imagem”, seja o decalque (Abbild) que reproduz um ente, dado ou que cessou de ser presente, seja o modelo (vorbildender Anblick) que projeta um ente ainda por ser criado. [...]

Emprega-se também frequentemente a palavra imagem nesse segundo sentido de decalque. Este objeto que se encontra aí, esta fotografia dada, oferece imediatamente uma visão enquanto ela é ela própria uma coisa; é uma imagem no sentido amplo e primeiro da palavra. Mas ao mesmo tempo em que ela é ela própria manifesta, ela torna manifesto o que ela reproduz. De acordo com esse segundo sentido, obter uma imagem não equivale a dar-se apenas a intuição imediata de um ente mas, por exemplo, a tirar uma fotografia ou comprar uma.

Pode-se, de uma tal reprodução, tirar uma nova reprodução, como quando se fotografa uma máscara mortuária. A reprodução representa imediatamente a máscara mortuária e, dessa forma, também a própria "imagem" do morto (do qual ela nos dará uma visão imediata). A fotografia da máscara mortuária é, enquanto reprodução de uma reprodução, ela própria uma imagem, mas ela só o é porque apresenta a "imagem" do morto, mostrando-o a nós tal como ele aparece, tal como ele apareceu.*

Num recente comentário dessas páginas, Jean-Luc Nancy chamou a atenção para a importância - "como à revelia do próprio Heidegger”- de tal exemplo. De um lado (razão empírica), o filósofo havia podido contemplar o extraordinário atlas de máscaras mortuárias fotografadas na obra de Ernst Benkard, Das ewige Antlitz, publicada em 1926 e frequentemente reeditada na Alemanha.* De outro lado (razão especulativa), esse exemplo contribuía para fundar a imagem como conceito, ou seja, fundar o conceito de imagem como "transposição sensível dos conceitos":

A transposição sensível, segundo os diversos significados acordados até o presente à palavra "imagem”, visa ora ao modo da intuição empírica imediata, ora ao modo da apreensão imediata de uma reprodução que oferece a visão de um ente. 
Mas a fotografia é também capaz de mostrar como aparece, em geral, uma máscara mortuária. A máscara mortuária pode manifestar, por sua vez, como aparece, em geral, a face de um cadáver. Ora, é o que manifesta também um cadáver individual. A máscara mortuária pode também mostrar o aspecto de uma máscara mortuária em geral, assim como a fotografia pode manifestar não apenas o objeto fotografado mas ainda o que é uma fotografia em geral.

Mas o que manifestam precisamente as visōes (imagens no sentido mais amplo) deste morto, desta máscara, desta fotografia, etc.? Que aspecto (eidos, idea) nos apresentam? O que transportam para o sensível? Elas manifestam como uma coisa aparece "em geral", segundo o elemento que, nelas, é idêntico, válido para diversos. Ora, a unidade válida para diversos é o que a representação representa segundo a modalidade do conceito. Essas imagens suprem, portanto, a transposição sensível dos conceitos.*

Essa passagem filosófica da "intuição empírica imediata" ao conceito, e portanto da imagem-singularidade à imagem-unidadeque é imagem "em geral", isto é, "válida para diversos" -, terá sido possível, evidentemente, graças ao recurso ao "esquematismo". Está aí, diz Heidegger, o "cerne de toda a obra" kantiana, um de seus grandes momentos, um de seus grandes valores de uso. Ela permite que se forme uma noção da "imaginação transcendental" como "função unificadora" e "realização da [própria] transcendência". Ela quer subsumir, ou conjurar, a dispersão das imagens sensíveis; ela procura atingir essa "imagem pura" compreendida como "unidade reguladora” e como transposição conceitual. Assim, o professor de geometria, ao traçar um triângulo no quadro negro, fornece-nos uma imagem em geral "representada em sua função de regra", isto é, como um "idêntico válido para diversos".*

Eis como, aos olhos de Jean-Luc Nancy, a tradicional "imagem enquanto mentira" pôde, graças a Kant, dar lugar à "verdade enquanto imagem”. E isso só terá sido possível através de um pensamento de imagem-sintese precisamente engajada pela noção de esquema. * Graças ao esquema e sua famosa "arte oculta", ao esquema e sua magia filosófica, as imagens seriam um pouco menos dispersas, um pouco mais previsíveis - nesta verdadeira "pré-visão da imagem" que o esquematismo instaura -, prometidas enfim à $E i$ nung e à Einigung, à unidade e à unificação em que o fazer-imagem (Einbildung) deverá ser desde então compreendido.

É o esquema do um enquanto sucessivo de si próprio. É a imagem pura (o esquema é imagem não sensível) através da qual, em ge-
*(HEIDEGGER, Martin. Kant et le problème de la métaphysique. op. cit.: 152.)

* (Ibidem: 147 e 154-159.)

* (Cf. NANCY, Jean-Luc. "L'imagination masquée" (2002). Au fond des images. op.cit.: 147-148.) 
ral, uma imagem é possível, ou seja, através da qual a unidade e a unicidade de uma representação são possíveis. [...] [É] a Einung do Bild (Einung é uma antiga forma poética, rara, para Einigung, unificação). É o fazer-um, o fazer-entrar-no-um do Bild. Trata-se de uma pré-visão da imagem, da abertura a uma visão em geral.*

Ora, se mantivermos em mente a análise de Lévinas - da qual, sem dúvida, Jean-Luc Nancy nada ignora -, não deveríamos supor que Blanchot desenraíza essa Einbildung heideggeriana e, com ela, o próprio Esquematismo Kantiano? A imagem-despojo já não é, ainda é, uma imagem-unidade, uma imagem-síntese? Se Heidegger, em seu texto, nada diz da máscara como dissimulação, não seria precisamente para salvaguardar a "função reguladora" da imagem em geral? Seria suficiente articular a imagem à morte - como demanda, arqueologicamente, a própria noção de imago - para ancorar a imagem-despojo na unicidade do Bild heideggeriano? O impasse do filósofo sobre o movimento "da morte à morte" - que Nancy observa muito bem - não seria justamente o índice de mal-estar fundamental em relação a qualquer esquematização da imagem?6

* Figura 5: Anônimo alemão. Máscara mortuária de G. W. F. Hegel, 1831. Gesso. Marbach, Schiller-National-museum. Foto D. R.
Figura 5*

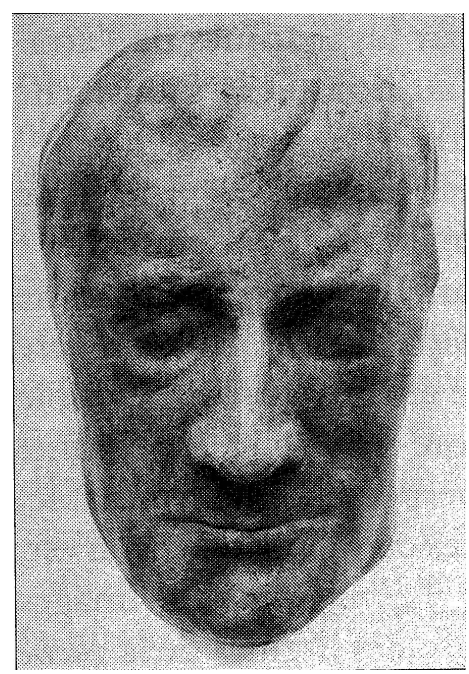

Para qualquer pessoa que tenha tido em suas mãos uma máscara mortuária, o contraste permanece impressionante entre a experiência concreta das imagens-despojos e as pretensões especulati-

\footnotetext{
${ }^{6}$ Ibidem: 168 (E em nota, o filósofo observa: "Seria interessante estabelecer uma relação com a análise proposta por Blanchot da imagem como semelhança mortuária”.) e 171-177.
} 
vas da imagem-sintese. A ruminação de que fala Blanchot é obsidionalidade no espaço, obsessão no tempo: isso implica que o interminável não se "desenrola" como a sucessão de que falava Kant a respeito do "um que se sucede dando-se ou abrindo-se uma possibilidade de imagem". 7 Quando Heidegger, por sua vez, coloca um traço de união entre a aparição do morto, sua máscara mortuária, a fotografia desta e a reprodução da fotografia, ele se posiciona na ordem especulativa de uma tal sucessão, mas não numa fenomenologia da ruminação imaginária.

\section{Figura $6^{*}$}

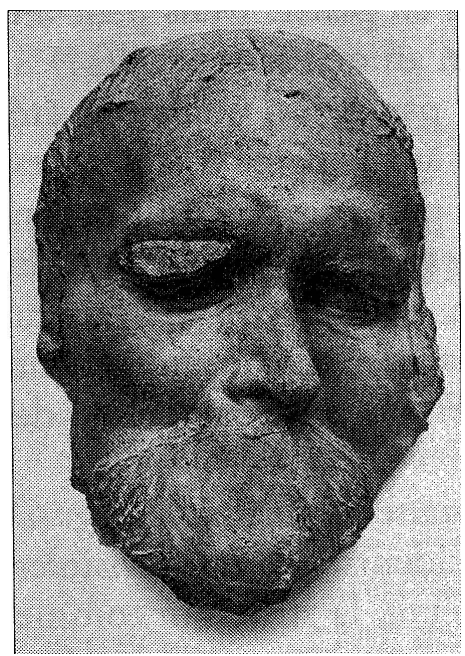

Nessas condições, a pré-visão que a imagem-sintese supostamente fornece - permitindo-nos, por exemplo, saber, antes de qualquer olhar lançado ao rosto de um morto ou a uma máscara funerária, "como aparece em geral a face de um cadáver" -, ${ }^{*}$ esta esperança especulativa choca-se com a soberana imprevisibilidade de qualquer encontro com uma imagem-despojo. Era imprevisível, mesmo que isso tenda a fazer sentido a posteriori, que a máscara mortuária de Hegel, na coleção publicada por Benkard, pudesse assemelharse a um seixo carregado durante muito tempo pelo mar, encerrado em sua ausência de órbitas, apertado na severa linha de lábios, tão esquecido de sua carne, de sua cabeleira, tão recluído em sua

\footnotetext{
${ }^{7}$ Ibidem: 150. O texto original é o de E. Kant - "Du schématisme des concepts purs de l'entendement”. Critique de la raison pure (1781-1787). Trad. de A. Tremesaygues e B. Pacaud. Paris: PUF, 1944 (ed. 1971): 150-156 -, no qual o esquematismo é exposto através dos exemplos do triângulo e da sucessão numérica.
}

* Figura 6: Anônimo alemão, Máscara mortuária de F. Nietzsche, 1900. Gesso. Marbach, Schiller-Nationalmuseum. Foto D. R.

* (HEIDEGGER, Martin. Kant et le problème de la métaphysique. op. cit.: 152.) 
* (U. Ott e F. Pfäfflin (dir.). Archiv der Gesichter. op. cit.: 330-331 (Hegel) e 353 (Nietzsche).) máscara de Nietzsche* pudesse assemelhar-se a esta coisa acidentada, assimétrica, invadida pelas marcas da violenta retirada, de modo que as sobrancelhas façam como uma ferida na testa e o bigode como uma grande mordaça a sufocar, talvez, um grito.

O "desenraizamento" ontológico evocado por Lévinas em relação a Blanchot toca, portanto, também as noçôes de imagem e de semelhança: a imagem não unifica tanto quanto esperava Kant, a semelhança não se assemelha tanto quanto esperava Heidegger (e mesmo tanto quanto sugere Nancy). ${ }^{8}$ A unificação entra em choque, na existência efetiva e imprevisível das imagens - à qual os filósofos são ainda com demasiada frequência, como por ofício, desatentos -, com esta disseminação perpétua, interminável, que as torna tão frágeis, tão lacunares e tão necessárias ao mesmo tempo. Com todo rigor, é impossível caracterizar a Einigung das imagens mortuárias de Hegel ou de Nietzsche: cem minúsculos dramas da tuchè e da technè modificaram a semelhança desses rostos, e depois dessas coisas. Cem metamorfoses de plasticidades, de resistência ao material, de escolhas técnicas, de poses, de acidentes processuais, de "despojos" ou de "contra-despojos" (exemplo de contra-despojos evitados: Hegel e Nietzsche não têm mais orelhas em suas imagens em gesso. Mas pode-se imaginar que um grande filósofo se assemelhe a um animal sem orelhas?).

Pior: as tiragens entre elas não se assemelham, conforme foram ou não retrabalhadas.* Que sejam evidentes ou que mal se possa vê-las, as diferenças entre imagens sucessivas acabam por arruinar a própria unificação da "visão". Antes mesmo que Heidegger tivesse gravemente postulado essa unificação da semelhançano exemplo do rosto, da moldagem e da fotografia -, Marcel Duchamp havia, ironicamente, mas eficazmente, reivindicado a in-

\footnotetext{
${ }^{8} \mathrm{Na}$ realidade, Jean-Luc Nancy parece-me deixar a questão em suspenso: de um lado, ele conclui sua obra com o Einbildung heideggeriano e o papel crucial que nele representa a imagem-esquema; por outro lado, o primeiro texto de sua coletânea ("L'image - le distinct") sugere um caminho de pensamento completamente diferente. Cf. J.-L. Nancy. Au fond des images. op. cit. : 11-33. Por outro lado, descubro que minha hipótese se alia, quanto à questão da imagem, à análise proposta por Leslie Hill sobre o "diferendo" entre Blanchot e Heidegger a respeito do ato poético. Cf. Leslie Hill. Blanchot: Extreme Contemporary. Londres/ Nova York: Routledge, 1997: 77-91. Leslie Hill. "Ein Gespräch: Blanchot depuis Heidegger jusqu’à Hölderlin”. Revue des sciences humaines, número 253, 1999: 187-208.
} 
fra-leve diferença no próprio cerne de toda reprodutibilidade técnica das imagens.*

Basta olhar novamente a máscara mortuária de Nietzsche* para nela notar um trabalho onipresente dos acidentes, das imprevisíveis diferenças: elas atingem o todo como o detalhe, a estrutura como a textura. Compreende-se que esse objeto tenha estado rente à semelhança cadavérica, compreende-se também que nada mais se assemelhará a esse objeto, porque essa semelhança não poderá jamais ser instituída - nos manuais de filosofia, por exemplo - como a imagem-sintese de Friedrich Nietzsche. Demasiado singular, ela não pode ser unificada. Demasiado próxima dos despojos, ela só pode ser uma imagem-arrancamento. Por que isso? Notadamente, porque, nesse rosto, reinavam os pelos - esses pesadelos do idealismo 9 - impossíveis de serem moldados como tais, impossíveis de serem erigidos em efígie e que, na máscara, desencorajam ou desfiguram qualquer veleidade de retrato: ali onde reinavam os pelos (no rosto), aqui fatalmente reina o arrancamento (na imagem).

Blanchot pensava ainda a imagem sob o ângulo da Einbildung? Não seria preciso, antes, reportar a imagem à interminável disseminação e a este "pensamento do fora" que exigiria, talvez, pensar algo como uma Ausbildung das semelhanças, para além do sentido comum da palavra? Não é preciso emitir a hipótese de que Blanchot, a esse respeito, terá antes retido uma lição de Sartre que, em A Imaginação, havia visto o esquematismo kantiano apenas como que uma bricolagem hábil, mas pouco produtiva para dar conta da fecundidade imaginária?

Quanto ao esquema, ele representa simplesmente uma tentativa de conciliação entre dois termos extremos. Mas o próprio fato de se utilizar essa noção mostra bem que se persiste a afirmar a existência desses extremos. Sem imagens-coisas, não há necessidade de esquemas: em Kant, em Bergson, o esquema nunca passou de uma artimanha para reunir a atividade e a unidade do pensamento à multiplicidade inerte do sensível. A solução do esquematismo aparece, portanto, como uma resposta clássica a uma certa maneira de formular a questão. Com um outro enunciado, a própria significação do esquema desaparece. [...] Todo o mal nasceu do fato de que se veio à imagem com a ideia de sintese [...]. A imagem é um ato e não uma coisa.*

\footnotetext{
${ }^{9}$ Desde o texto famoso de Platão, Parmênides, 130 a.C., no qual "a Ideia do homem" encontra-se confrontada a "pelo, lama, imundície, ou qualquer outra coisa, a mais desprezível e a mais vil”.
}

* (Cf. DIDI-HUBERMAN, Georges. L'Empreinte. op. cit.: 106-179.)

* (figura 6)
* (SARTRE, Jean-Paul. L'Imagination (1936). Paris: PUF, 1971: 70 e 162.) 
Um ato e não uma coisa: um gesto - interminavelmente prolongado, variado, coreografado - e não uma síntese. Uma imprevisível epidemia de semelhanças impossíveis de serem reunidas e não uma previsível sucessão de aspectos congruentes. Um conhecer, não um reconhecer. Para tocar esse "meio absoluto, ali onde a coisa volta a ser imagem”, para entrar nesse lugar e nesse tempo "em que a fascinação ameaça”, não era preciso nada menos do que correr o risco de romper a Einigung, a unidade ou o arranjo do próprio pensamento.

Tradução de Maria José Werner Salles

(Doutoranda em Literatura na Universidade Federal de Santa Catarina)

\section{Georges Didi-Huberman}

É filósofo, historiador de arte e crítico de arte. É pesquisador na École des Hautes Études en Sciences Sociales, em Paris, e autor de uma obra complexa, com mais de trinta livros já publicados. Dialoga em seus livros com escritores e pensadores como Carl Einstein, Aby Warburg, Walter Benjamin, Georges Bataille, Freud e Pierre Fedida, entre muitos outros. Ensinou em universidades estrangeiras como Johns Hopkins, Northwestern, Berkeley, Courtauld Institute, Berlim e Basileia. Recebeu o Hans-Reimer-Preis da AbyWauburg-Stiftung de Hamburgo e o prêmio Humboldt, em 2006. Dirigiu inúmeras exposições como L'Empreinte no Centro Georges Pompidou, em Paris, em 1997 e Fables du lieu no Studio National des Arts Contemporains, em Tourcoing, em 2001. Realiza em 2011, em Madri, uma exposição no Museu Reina Sofia sobre o Atlas Mnemosyne de Aby Warburg.

Palavras-chave: semelhança; imagem; Blanchot; Didi-Huberman; linguagem; "meio absoluto".

\section{Resumo}

$\mathrm{O}$ artigo analisa a imagem e a semelhança como condições essenciais na experiência literária de Maurice Blanchot, discutindo, a partir de várias obras do escritor, as relaçōes entre linguagem e imagem. Trabalha-se em especial a noção de "meio absoluto", invocada por Blanchot para descrever o devir-imagem da linguagem na literatura. 


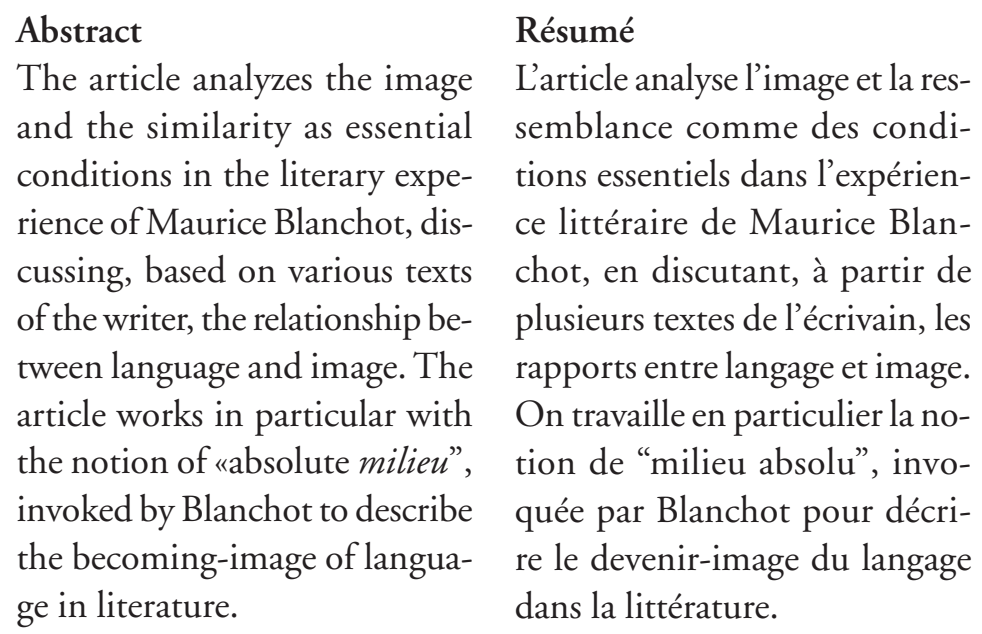

Keywords: similarity; image; Blanchot; Didi-Huberman; language; "absolute milieu".

Mots-clés: ressemblance; image; Blanchot; Didi-Huberman; language; "milieu absolu". 